\title{
CONTRADICTION AND AMBIVALENCE: VIRGINIA WOOLF AND THE AESTHETIC EXPERIENCE IN "THE DUCHESS AND THE JEWELLER"
}

\author{
LAURA María LOJO RODRÍGUEZ \\ Universidad de Santiago de Compostela
}

\begin{abstract}
In the midst of the terror waged on Europe by Nazi demonstrations of power and racial extermination Virginia Woolf published a most contrevorsial short story - "The Duchess and the Jeweller" (1938) - which was originally entitled "The Duchess and the Jew" but was changed at the request of Woolf's American publisher for its racist connotations. The story has been neglected by the critics on account of two major reasons: on the one hand, it does not partake of those innovative narrative devices that most of Woolf's fiction presents; on the other such an apparently Anti-Semitist piece of work is inconveniently at odds with the oeuvre of a writer who so ardently and energetically rejected Fascism in her pamphlet Three Guineas which was curiously simultaneous in date of composition and publication to "The Duchess and the Jeweller".

Despite the fact that Woolf may have been airing her personal prejudices of race and class in the characters of Oliver Bacon and the Duchess of Lambourne, the present paper does not aim to do away with such incoherence, ambivalence and contradiction, but rather focuses on the jewel imagery which structures the narrative and which addresses questions such as the 'art for art's sake' doctrine versus the material commodity of beauty.
\end{abstract}

1.

In the midst of the terror waged on Europe by Nazi demonstrations of power and racial extermination, Virginia Woolf wrote the short story "The Duchess and the Jew" (1938) whose original title was later changed to "The 
Duchess and the Jeweller" at the request of Woolf's American publisher. From the very moment of its composition and publication, the story was controversial for its blatant Anti-Semitist attitude: it was difficult for critics and audience alike to account for such a racist portrait of a Jew, which was so inconveniently at odds with the oeuvre of a writer happily married to a Jew for more than thirty years. Moreover, Woolf ardently and energetically rejected war and opposed Fascism and its racial policy, especially in her pamphlet entitled Three Guineas (1938), the date of publication of which was simultaneous with "The Duchess and the Jeweller".

Despite the critics' attempts to resolve this apparent incoherence in Woolf's attitude, it seems that Woolf was airing her personal prejudices of race and class in the characters of Oliver Bacon and the Duchess of Lambourne, the Jew and the aristocrat respectively. ${ }^{1}$ The present paper does not aim to do away with Woolf's ambiguity, but rather focuses on the very question of the contradictions which structure the process of composition and publication of the story as well as its very meaning. As will be argued, the story should be seen in relation to British aestheticism, about which Woolf herself was ambivalent. More importantly, aestheticism represented the embracing of contraries, for it articulated itself as both "high art" and as a mass-cultural movement; its predicament of l'art pour l'art was only validated when, ironically, art became a commodity in a consumerist society. In "The Duchess and the Jeweller" the jewel imagery which permeates the story is itself a reflection of such a fascinating contradiction: on the one hand, it partakes of a tradition where it came to symbolise eternal beauty; on the other, it calls attention to the nature of art as commodity, for it also introduces the question of material value.

By the time "The Duchess and the Jeweller" was written, Virginia Woolf was a reputed writer, essayist and publisher, but she felt that her whole world view was about to collapse under the threat of a second war. Arguments over its inevitability made more than evident Woolf's dislike for a society of which she was part and for which she was meant to feel patriotic: "What would war mean? Darkness, strain: I suppose conceivably death. And all the horror of

1. Hermione Lee (1996: 680) points how "it is hard not to read these as examples of offensive caricature". However, the very act of creating those characters is, for Lee, a symptom of Woolf's detachment "from the habitual Anti-Semitism of her circle" by spelling out "her complicity in bigotry and offensiveness by way of self-accusation and social critique". Other critics simply dismiss "The Duchess and the Jeweller" as a "conventional plot-bound story" (Head 1992: 80) or as a "mere satirical portrait" (Guiguet 1965: 341). For a similar approach, see also John Hagopian \& Martin Dolck (eds.), (1964: 363-367) and Dean Baldwin, (1989). 
friends... All that lies over the water in the brain of that ridiculous little man" (Woolf 1984: 166). It seemed to Woolf (1984: 204) that the imminence of war absorbed the attention of a reading public formerly interested in her work, a feeling which deepened her own insecurity and heightened the sense of the "decline of her fame".

Although her nephew's death in August 1937 while working as a volunteer for the Republican army in the Spanish Civil War enhanced Woolf's repulsion to war, at the same time it clarified the way to demonstrate her resistance to it: "Thinking is my fighting" (Woolf 1984: 285). At that time Woolf was finishing the afore mentioned pacifist and anti-Fascist pamphlet entitled Three Guineas and Julian Bell's death made it possible for her to see the work under a different light as well as to finish its last chapter, which she explained to her sister Vanessa in this way: "I'm always wanting to argue it [Three Guineas] with Julian -in fact I wrote it as an argument with him. Somehow he stirred me to argue" (1980a: 159). Woolf reinforced the two aspects she had often discussed with Julian; namely writing being more effective than fighting, and war being directly connected to patriarchy: "Here, immediately, are three reasons which lead your sex to fight; war is a profession; a source of happiness and excitement; and it is also an outlet for manly qualities, without which men would deteriorate" (Woolf 1938: 160). As Alison light has posed (2002: 29), Woolf's anti-militarism stands not only for her rejection of a bellicose positioning but also for her contestation of all forms of masculine authority and authoritarianism.

Such was Woolf's inflexibility about war, Fascism and the racial extermination that it implied and of which she was well aware. Curiously, following the previous diary entry Woolf records in her diary how she was also engaged in writing a story for her New York literary agent, Jacques Chambrun, who had offered $\$ 1000$ for a story whose process of composition Woolf describes in the following terms: "This morning I had a moment of the old rapture... over copying The Duchess \& the Jeweller, for Chambrun, NY. I had to send a synopsis. I expect he'll regret the synopsis. But there was the old excitement... more than in criticism, I think" (1984: 107). On the same day Woolf summarises its plot for Vanessa: "I've made up a story about a jeweller and a duchess, and cabled the plot -how he buys her pearls, for $£ 10,000$, knowing them to be false- that's not all of it by any means" (1980a: 159).

Although Chambrun initially approved of her synopsis, he later cabled Woolf to change what the American market would see as "a terrific racial prejudice" (Lee 1996: 679). In that first draft of the story, the jeweller was named "Isadore Oliver" and had been a "little Jew boy" who made his way through life by dishonest means from a "filthy little alley" to a luxurious flat overlooking Green Park. As a result of both Chambrun's and his "unknown” client's objections, "Isadore" became "Oliver", although the surname was tellingly changed to "Bacon", which may refer to the prohibition to eat pork 
in the Jewish tradition, and "the little Jew boy" became "the little boy". Nevertheless, the word "Jew" was still retained as part of the story's very title, "Jeweller". ${ }^{2}$

As stated earlier, it is indeed difficult to understand why a person who was apparently happily married to a Jew should portray a character in such a racist light. ${ }^{3}$ Hermione Lee argued (1996: 680) that Woolf may have been spelling out her complicity in the habitual, half-conscious Anti-Semitism of her Bloomsbury circle and conceived of the story as both self-accusation and social critique. At the same time, it seems that Woolf was airing her private prejudices of race and class in the characters of both Oliver Bacon and the Duchess of Lambourne ${ }^{4}$ : in fact, the gentile duchess of the story is as much an outsider of acceptable society as the Jew himself. Interesting as Woolf's ambivalence and incoherence is, her personal contradictions are legitimate and deserve to be left untouched. 5

Yet when the story is seen from the perspective of British Aestheticism, such contradictions become utterly revealing and significant in structuring meaning in "The Duchess and the Jeweller". As the story begins, Oliver Bacon is introduced in his ostentatious London flat while he reflects, with considerable self-satisfaction, on his rise from a boy who sold stolen dogs to a jeweller rubbing shoulders with aristocracy in his present opulence:

'Behold, Oliver,' he would say addressing himself. 'You who began life in a filthy little alley, you who...' and he would look down at his legs,

2. After further dealings with Chambrun and Leonard Woolf's intervention, the story was published -along with "The Shooting Party"- in successive issues of Harper's Bazaar both in London (April 1938) and New York (May 1938). Eventually Virginia Woolf received a total of $\$ 960$ for the two of them. For further details on the composition and publication process of the story, see Hermione Lee (1996: 678-680), Susan Dick (Woolf 1985: 314-315) and Sandra Kemp (Woolf 1993: 121-123).

3. To Ethel Smyth Virginia Woolf wrote: "How I hated marrying a Jew... what a snob I was" (1978: 194).

4. As argued above, "The Duchess and the Jeweller" was published along with "The Shooting Party", and both were conceived by Woolf as a series of caricatures: "I could write a book of caricatures. Christabel's story of the Hall Caines suggested a caricature of Country house life, with the red-brown pheasants..." (1982: 57). The story traces the decadence of a family of country squires in a non-aristocratic world and whose name is extinguished with their last three members.

5. In her review of Naomi Black's edition of Three Guineas (London: Blackwell's, 2001), Alison Light (2002: 30) highlights the tendency of some critics to "consistently omit and truncate those comments which suggest [Woolf's] ambivalence about her work". Such an effort obviously responds to an anxiety to sketch out a coherent political or artistic positioning in Woolf's oeuvre which contradiction and ambivalence could taint, but, in Light's words, "it's equally odd that (...) scholars should see its role as celebratory, preaching only to the converted" (2002: 31 ). 
so shapely in their perfect trousers; at his boots; at his spats. They were all shapely, shining; cut from the best cloth by the best scissor in Savile Row. (Woolf, 1985: 248)

Oliver strolls to the shop he runs in Bond Street and ignores his subordinates as he passes them feeling sure that they are envious of him. Once in his office, he takes out some jewels from the safe and greedily admires them. The telephone announces that the Duchess of Lambourne has arrived for her appointment, but Oliver chooses to keep her waiting for ten minutes. The decadent and glamorous Duchess wishes to sell the last of her pearls, whose authenticity the astute Oliver doubts, in order to pay off her gambling debts. The Duchess invites Oliver to spend a long weekend in her country house, where he will meet the Prime Minister, His Royal Highness... and her daughter Diana, for whom Oliver lustfully yearns. Eventually, Oliver writes a cheque for twenty thousand pounds, despite now knowing for certain that the pearls are false.

2.

Even after a surface reading of the story, it is obvious that "The Duchess and the Jeweller" is much more than a racist portrayal of a Jew which makes the reader uneasy knowing Woolf's background: as Virginia Woolf herself had explained to her sister after sketching out a synopsis, "that's not all of it, by any means" (1980a: 159; my italics). The reader is left with the feeling that what is for sale is something infinitely more valuable than a set of false pearls. And significantly, the key to the story lies deeply rooted in the question of beauty, aesthetics and literary value since, as Terry Eagleton (1975: 167) has argued and the story literally and metaphorically shows, value is always relational and can only be defined in terms of exchange.

As Eagleton suggests (1975: 166), the question of value can only be determined on the site of production. In other words, every text encodes within itself "how, by whom and for whom it was produced" (Feltes, 1986: 48), which is eventually what determines and produces its meaning, either it be conscious or unconscious. The question of literature as commodity is notably present in the process of composition of "The Duchess and the Jeweller" as well as in the text itself; as argued above, the story was commissioned by Woolf's American agent, and all references to it in her diary and in private correspondence are linked to the large amount of money she was to receive for writing it. After sketching out its plot to her sister, Woolf asks: "Do you think, knowing the Americans as you do, that this [the plot] will fetch them? It means 200 if it does" (1980a: 159).

Frivolous as this comment seems, Woolf (1984: 107-108) was, however, utterly worried about what she called the "moral temperature" when writing 
for money, as she records in her diary after having mentioned Chambrun's large sum for the story:

Do I ever write, even here, for my own eye? If not, for whose eye? An interesting question, rather. I'm musing on the nature of Auden's egotism. Suspect it's something to do with uneasiness. He wants to write straight from the heart: to discard literature; egotism may be his way of orienting himself. What I mean I don't quite know, perhaps that it seems to him that's being honest, simple, naked, taking off literary clothes".

The entry brings to the fore questions which concern the complicated relationship between an author and his or her readership, on which Woolf reflected in many different ways throughout her life. Woolf was consistent in defining her "aesthetic" against that of other modernist writers, regarding her own position as a novel-writer as highly competitive in the market. While engaged in the process of writing Jacob's Room (1922), she writes in her diary: "I see immense possibilities in the form I hit upon more or less by chance 2 weeks ago. I suppose the danger is the damned egotistical self; which ruins Joyce and [Dorothy] Richardson to my mind" (1981: 14; my italics).

Unlike some of her contemporaries, Woolf regarded the idea of "writing for a small public" as "damnation" (1976: 168) and always established a relation of kinship with her readers, which she argued in "Hours in a Library" (1916): "Indeed, one of the signs of passing youth is the birth of a sense of fellowship with other human beings as we take our place among them" (1987: 57). Towards the very end of her life, Woolf developed a similar image -literature as a "common land"- which appeared in her famous essay "The Leaning Tower" (1940), along with the writer's desire to be "whole" and "human" and whose aim is to be "closer to their [the writers'] kind (...) no longer to be isolated and exalted in solitary state upon their tower, but to be down with the mass of human kind" (1992: 173).

Yet, as Woolf herself acknowledged, her position was a privileged one in the British marketplace as owner of a publishing house, the Hogarth Press, which was invaluable in granting her intellectual as well as economic freedom. As Laura Marcus has suggested (1996: 142), the Press became for Woolf synonymous with the room of one's own and the $\$ 500$ a year she had described as the necessary conditions for the woman writer, thus allowing her to devote her energies to revising and inventing forms of fiction: "I'm the only woman in England free to write what I like (...) [whereas] the others must be thinking of series and editors" (1980b: 43).

Notwithstanding, Woolf's relationship to literary culture and professionalism is a highly complex issue. As Elliott and Wallace have posed (1994: 141), Woolf did not escape from the tension felt by modernist women writers and artists who had to choose between economic compensation and a right to fair wages for cultural production and the Modernist ideology of 
artistic and financial disinterestedness. Very few professional women are found in Woolf's work: both Lily Briscoe in To the Lighthouse (1927) and Miss La Trobe in Between the Acts (1941) are amateurs and outsiders. Yet Woolf was also intrigued by the idea of writing as a profession, thus elaborating histories of professional women writers like in A Room of One's Own (1929) or in the many articles devoted to the literary lives of women in The Common Reader (1925). Said elaboration helped her to rescue from oblivion a tradition of foremothers that enabled her to write her own history as a woman of letters, which she did in "Professions for Women" (1931):

It is necessary to discuss the ends and the aims for which we [professional women] are fighting, for which we are doing battle with these formidable obstacles. Those aims cannot be taken for granted; they must be perpetually questioned and examined. The whole position, as I see it -here in this hall surrounded by women practising for the very first time in history I know not how many different professions- is one of extraordinary interest and importance. You have won rooms of your own in the house hitherto exclusively owned by men. (1992c: 106)

Popularity was, however, a term towards which Woolf felt deep ambivalence: on the one hand, she delighted in high sales figures for her work; on the other, success -or, at least, in some of her contemporaries' snobbish view- might also imply writing potboilers for the masses. The popularity of Orlando (1928) led her to consider repeating herself rather than "keeping those good qualities [which] were largely the result of ignoring the others" (1980b: 209). While at work on Three Guineas, Woolf made a similar comment concerning "The Duchess and the Jeweller" which, she thought, would satisfy publishers while, at the same time, would prove largely rewarding in economic terms: "I'm completely stuck on my war pamphlet, so I may as well write about Duchesses" (1980a: 159).

Superficially, Woolf seems to be drawing a distinction between writing for money -her critical essays, articles and some of her short stories- and writing for "her own eye", as argued earlier: "This question of praise and fame must be faced (...) How much difference does popularity make? What depresses me is the thought that I have ceased to interest people - at the very moment when by the help of the press, I thought I was becoming more myself" (1981: 106).

As suggested earlier, the whole process of composition of "The Duchess and the Jeweller" is caught up in that tension between writing "for oneself" and satisfying commercial requirements which eventually grant economic rewards. Significantly, the most important issues which concern the very story go beyond Woolf's possible prejudice of race and class and are deeply related its site and process of production. As will be argued below, "The Duchess and the Jeweller" exemplifies Woolf's ambiguous and complex attitude and relationship to the mass market and the consideration of art as a commodity. 
"The Duchess and the Jeweller" should be seen in relation to British aestheticism, especially as understood by Walter Pater and Max Beerbohm. Aestheticism articulated its status as both high art and a mass-cultural movement, thus embracing the two contradictions which haunted Woolf in the process of composition of the story. This movement, which took place during the second half of the nineteenth-century and the early part of the twentieth, is loosely connected by the phrase which the poet Swinburne popularised, l'art pour l'art and manifested itself not only in poetry, painting and literature, but also in dress, furniture design and popular narrative genres. ${ }^{6}$

On a superficial level, British aestheticism is related to decadence -with its fascination with the unnatural, death, decay, the body- as well as to artifice, intense experience and the desire to experience life as art. Yet, and as Peter Bürger (1984: 8) has suggested, aestheticism is also and more importantly a particular historical condition of art in bourgeois culture: when art is separated from the constraints of church, court and state and is distributed through the capitalist market-place, it becomes autonomous.

And yet, and in a more surface sense, British aestheticism seemed to be related to artifice, frivolity, inconsequentiality and decadence alike (Freedman 1990: 1). Max Beerbohm? (1895: 278-279) described it as "the discovery of the

6. Aestheticism permeated not only Woolf's work, but also the predicaments and imagination of most Bloomsbury members. One of the most outstanding aspects of the professionalisation of aestheticism was the constitution of the "art expert" and the emphasis on artisan work, an example of which was the Omega Workshop, opened from 1913 to 1919 and ran by Roger Fry, Vanessa Bell and Duncan Grant. Although originally the Omega Workshops aimed at producing decorative art from a background of painting rather than crafts, a huge range of products were sold, including lamps, rugs, screens, necklaces, parasols, furniture, textiles, dresses, mosaics and murals.

7. Max Beerbohm (1872-1956) was one of Woolf's most admired essayists and writers. "The Modern Essay" -one of Woolf's most famous reflections on the art of essay-writing, included in The Common Reader (1925)- is largely a praise of Beerbohm's contributions to the genre which, according to Woolf, are only comparable to those of masters such as Michel de Montaigne or Charles Lamb. Woolf described Beerbohm as "the prince of his profession [essay-writing]", responsible for modernising the essay by bringing "personality into literature, not unconsciously and impurely, but so consciously and purely that we do not know whether there is any relation between Max the essayist and Mr Beerbohm the man. We only know that the spirit of personality permeates every word that he writes" (Woolf 1994: 220-221). In her diary, Woolf described her first encounter with Beerbohm at Ethel Smyth's house. Tellingly, Woolf uses the jewel imagery in order to refer to Beerbohm's writing qualities: "So I said, I think he is immortal. In a small way, he said; but with complacency. Like a jewel which is hard \& flawless, yet always changing. A charming image, he said, very kind, approving" (1980b: 213; emphasis mine). 
cult of Beauty", the result of which was that,

(...) Peacock feathers and sunflowers glittered in every room, the curio shops were ransacked for the furniture of Annish days (...) A few smart women even dressed themselves in suave draperies and unheard-of greens. Into whatever ballroom you went, you would surely find (...) women in tiaras and the fops of distinguished foreigners.

Such a luxurious and opulent, yet at the same time decadent and corrupted atmosphere also surrounds the characters of both Oliver Bacon and the Duchess of Lambourne in "The Duchess and the Jeweller", appearing in opposition to the world which the flaming jewels evoke. Oliver's flat, "at the top of a house overlooking the Green Park", has been expensively decorated in -as the narrator ironically suggests- a nouveau riche's style: "Sofas filled the bays of the windows -sofas covered in tapestry. The windows, the three long windows, had the proper allowance of discreet net and figured satin. The mahogany sideboard bulged discreetly with the right brandies, whiskeys and liqueurs" (Woolf 1985: 248). Likewise, the Duchess is described as the epitome of pomp and arrogance, whose apparent opulence stands out given her ruined morals and possessions:

And as a wave breaks, she [the Duchess] broke, as she sat down, spreading and splashing and falling over Oliver Bacon the great jeweller, covering him with sparkling bright colours, green, rose, violet; and odours; and iridescences; and rays shooting from fingers, nodding from plumes, flashing from silk; for she was very large, very fat, tightly girt in pink taffeta, and past her prime. As a parasol with many flounces, as a peacock with many feathers, shuts its flounces, folds its feathers, so she subsided and shut herself as she sank down in a leather armchair. (Woolf 1985: 251)

Woolf presents the characters of the duchess and the jeweller against a decadent backdrop both in its literal and more superficial aesthetic sense of the word, which recalls Beerbohm's description of such a world. They represent the epitome of a society void of values, which is what essentially brings them together: "As their hands touched the link was forged between them once more. They were friends, yet enemies; he was master, she was mistress; each cheated the other, each needed the other, each feared the other" (1985: 251). Oliver and the Duchess share a ridiculously obscene relationship of self-interest and animal greed, which is emphasised by the animalisation of each one of the characters: the Duchess is described as a "peacock with many feathers"; Oliver is alternatively identified with an "elephant", a "giant hog" and a "camel" (1985: 249). Moreover, both the unscrupulous self-made man and the adulterous gambler contemplate the pearls that are for sale and the jewels 
become their object of desire despite the differences in their class and race:

The Duchess opened; her heart, her private heart, gaped wide. And with a sigh, but no words, she took from her bag a long wash-leather pouch -it looked like a lean yellow ferret. And from a slit in the ferret's belly she dropped her pearls -ten pearls. They rolled from the slit in the ferret's belly -one, two, three, four- like the eggs of some heavenly bird. (1985: 251-252)

The situation blatantly encodes a game of power and heterosexual desire enhanced by the use of sexual language where roles -"deceive the deceiver"- are constantly reversed: the authenticity of the pearls is always in question ("'Are they false or are they real?', asked Oliver), yet it is clear that what Oliver is actually buying is the Duchess's youngest daughter and a long weekend "riding alone in the woods with Diana" (1985: 253). Significantly, in British aestheticism the jewel also stands for femininity and the female body, which is at the same time a common trope for art and artistry in a both male and female writing tradition that reaches back through Christina Rosetti, Laetitia Landon, Alfred Tennyson and Percy Bysshe Shelley.

However, on a more profound level, and as Jonathan Freedman has argued (1990: 202), much of the thinking about aestheticism has to do with its relation to modernism and to modernist writers, which, among other things, details the relation between art object and commodity. Although most modernist male writers often disavowed this influence, their female counterparts continued to find in aestheticism a rich resource for the production of art as well as an alternative tradition with which to defy highmodernist misogyny. Shaffer and Psomiades (1999: 8) emphasise the relevance of the relations between aestheticism and commodity culture, as well as between aestheticism and sexuality. These relationships are presented in Virginia Woolf's "The Duchess and the Jeweller" in a tantalising way and are basically reflected in the image of the jewel. Significantly, the very central image around which the story evolves appears related to both beauty and desire, which is made evident when Oliver greedily and lustfully contemplates the jewellery laid before him:

8. See, for example, Griselda Pollock, (1988); Richard Dellamora, (1990) and Kathy Alexis Psomiades, (1997).

9. See Angela Leighton (1992) 
He twisted a key; unlocked one; then another. Each was lined with a pad of deep crimson velvet; in each lay jewels -bracelets, necklaces, rings, tiaras, ducal coronets; loose stones in glass shells; rubies, emeralds, pearls, diamonds. All safe, shining, cool, yet burning, eternally, with their own compressed light. (1985: 250; emphasis mine)

Only the sight of all this beauty seems to compensate for Oliver's social world which, in spite of his wealth and position, is dull and unsatisfactory: "He was the richest jeweller in England; but his nose, which was long and flexible, like an elephant's trunk, seemed to say with a curious quiver at the nostrils (...) that he was not satisfied yet" (Woolf, 1985: 249). It is only when guarded by the darkness of his workshop that Oliver feels completely satisfied: the jewels that the Jew keeps in his safe and the thrill of owning them seem to satisfy Oliver's primitive greed as well as his "animal" nature, for they are, at the same time, a work of art and a commodity for sale and, at all times, Oliver's object of desire.

On a more metaphorical level, the flaming jewel is also a symbol of secular aesthetic value -art for art's sake and the autonomy aesthetic- a doctrine popularised by Walter Pater among others, a seminal figure in nineteenth-century British aestheticism and to whom Woolf was much indebted. In his influential work The Renaissance (1873), Pater repeatedly described beauty as a "gem" (1873: xxx); in a passage which brings to mind Oliver's shining jewellery in the safe of his workshop, Pater had defined the aesthete's aim as to keep beauty "safe" in "the narrow chamber of individual mind", for it to "burn always with this hard, gem-like flame, to maintain this ecstasy" (1873: 152; emphasis mine). Pater advocated for an Epicurean relish in receiving and reporting the multiplicity and intensity of impressions in such a way that, as he puts it, "not the fruit of experience, but experience itself is the end" (1873: 152). Similarly, Virginia Woolf describes her aesthetic search in terms which become revealingly familiar: "It is not exactly beauty that I mean. It is that the thing is in itself enough: satisfactory, achieved" (1980b: 62).

With Pater -as well as with John Ruskin, Dante Gabriel Rosetti or A. C. Swinburne- Romanticism reaches both its climax and exhaustion. As Jonathan Freedman put it, "they all represent the turn within Victorian culture to valorising art in general and visual art in particular as a means of provoking intense experience in a society that seems able to deaden the senses and the spirit alike" (1990: 2). Within this context, the jewel image outshines the devaluation and decadence of spiritual values.

4.

As argued throughout this paper, the question of value has to be placed on the site of production. In "The Duchess and the Jeweller", value and beauty 
are always relational and a matter of exchange, an issue which worried Woolf throughout the entire process of composing a story commissioned for money. Yet at the same time, Virginia Woolf was haunted by the idea that the artist's pursuit was beauty, by the conception of life as art and by the search of visual perceptions which may provoke an intense experience, which she explained in one of her most celebrated essays on this topic, "Street Haunting" (1927):

For the eye has this strange property: it rests only on beauty; like a butterfly it seeks out colour and basks in warmth. On a winter's night like this, when Nature has been at pains to polish and preen itself, it brings back the prettiest of trophies, breaks off little lumps of emerald an coral as if the whole earth were made of precious stone". (1994: 482483; my italics)

Though an aesthete in that sense of the word, and probably because of it, for Woolf the idea of the work of art beyond or outside the social realm was simply unacceptable. In 1920, she had published a short story entitled "Solid Objects" which she described to her sister as having "some points as a way of telling a story" (1978: 497). John, a promising MP, becomes obsessed with a search for lumps of glass that keep transforming their shapes in his head: "Looked at again and again half consciously by a mind thinking of something else, any object mixes itself so profoundly with the stuff of thought that it loses its actual form and recomposes itself a little differently in an ideal shape which haunts the brain when we least expect it" (1985: 104). John's apprehension of form brings to mind barren aestheticism, and especially Clive Bell's, Woolf' brother-in-law, doctrine of "significant form" with which Woolf was in open disagreement. According to Bell (1914: 68), "significant form" would be a combination of lines and colour in the gazer's mind that moves him or her aesthetically; as a result, all those objects "that provoke this emotion we call works of art".

For Woolf (1985: 104), however, to privilege the experience of art as an end in itself, to divorce it from its social dimension was to deny its value. Like John's lumps of glass, objects found in "waste land (...) thrown away, of no use to anybody, shapeless, discarded" cannot be considered works of art. Eventually, John loses all social relations and becomes a figure of insanity and alienation, detached from the system of the world.

Unlike John's irregular "gems", possessing no use or market value, Oliver's jewels do have a double dimension: on the one hand, the jewel represents beauty, the sublime, it "burns eternally" because the work of art is exempt from physical corruption. Yet on the other, the jewel is constituted as such only because it has a price, a market value; it is a commodity and that is why it exerts such fascinating power of attraction which transcends class, race, 
or gender: “'Tears!' said Oliver, looking at the pearls. -Heart's blood!' he said, looking at the rubies. -Gunpowder!' he continued, rattling the diamonds so that they flashed and blazed" (Woolf 1985: 250).

What is actually at stake in "The Duchess and the Jeweller" is the question of artistry, value and the commodification of beauty, and such issues, contradictory as they actually seem, are the defining qualities of British aestheticism (Freedman 1990: 6). As Terry Eagleton has argued (1990: 368), the autonomy of aesthetic came to be so by, ironically, integrating art in the capitalist mode of production and its consolidation as commodity. Aestheticism is both high art and mass-cultural movement; its desire to synthesise both results in a complicated vision which seeks to explore the experience of fragmentation, loss and disintegration. Aestheticism in England represents the embrace of contraries -art for art's sake and commodity culture; the exploration of cultural contradictions- the alienated artist and the political role for art itself.

"The Duchess and the Jeweller" should also be placed on its site of production, which becomes thus revealing as far as the significance of the story is concerned. While at work on it, Woolf was haunted by what she saw as a contradiction between "high art" and popularity, between writing "for her eye" and writing for the masses. The question brings the story close to its coetaneous Three Guineas, disparate as they both seem, for there too the question of art and the artist's pursuit of beauty on the one hand and art's social role on the other is present. According to Woolf, the artist "must refuse to sell his brain for money" and has to practise art "for the sake of the art" only (1938: 270). Privately, Woolf records in her diary the impossibility of writing just for the artist's own pleasure in order to avoid a certain "objectification" of the writer: "That phrase inhibits me: for if one writes only for one's pleasure, -I don't know what happens. I suppose the convention of writing is destroyed; therefore one does not write at all" (1980b: 201).

"The Duchess and the Jeweller" was conceived and published in the midst of its author's serious contradiction about its nature and its very convenience, questions that also appear reflected in the story's subject-matter and the imagery employed. This short story reflects Woolf's ambivalence with regards to class, race and nationality on a surface level; interesting as this may be, "that is not all, by any means". The initial embracing of contraries is gradually developed further and on several layers of meaning: Oliver's jewels not only reflect them all, but also reach back through a tradition which was in itself delightfully contradictory. 


\section{REFERENCES}

Baldwin, Dean. 1989. Virginia Woolf: A Study of Her Short Fiction. Boston: Twayne.

Beerbohm, Max. 1895. (1880). The Yellow Book 4: 275-283.

Bell, Clive. 1984 (1914). "The Aesthetic Hypothesis". Modern Art and Modernism: An Anthology. Eds. Francis Frascina and Charles Harrison. New York: Harper \& Row. 67-74.

Bürger, Peter. 1984. Theory of the Avant-Garde. Minneapolis: U of Minnesota P. Trans. Michael Shaw.

Dellamora, Richard. 1990. Masculine Desire: The Sexual Politics of Victorian Aestheticism. Chapel Hill: U of North Carolina P.

Eagleton, Terry. 1975. Criticism and Ideology: A Study in Marxist Literary Theory. London: Verso.

Eagleton, Terry. 1990. The Ideology of the Aesthetic. London: Basil Blackwell.

Elliott, Bridget, and Jo-Ann Wallace 1994. Women Artists and Writers: Modernist (Im)Positionings. London: Routledge.

Feltes, N. N. 1986. Modes of Production of Victorian Novels. Chicago \& London: U of Chicago P.

Freedman, Jonathan. 1990. Professions of Taste: Henry James, British Aestheticism and Commodity Culture. Stanford, California: Stanford UP.

Guiguet, Jean. 1965. Virginia Woolf and Her Works. London: The Hogarth P. Trans. Jean Stewart.

Hagopian, John, and Martin Dolck, eds. 1964. "Virginia Woolf's 'The Duchess and the Jeweller'". Insight II: Analyses of Modern British Literature. Frankfurt: Hirschgraben-Verlag. 363-367.

Head, Dominic. 1992. The Modernist Short Story: A Study in Theory and Practice. Cambridge: CUP.

Lee, Hermione. 1996. Virginia Woolf: A Biography. London: Chatto \& Windus.

Leighton, Angela.1992. Victorian Women Poets: Writing against the Heart. Charlottesville: U of Virginia P.

Light, Alison 2002. "Harnessed to a Shark". London Review of Books (21 March). 27-31.

Marcus, Laura. 1996. "Virginia Woolf and the Hogarth Press". Modernist Writers and the Marketplace. Eds. Ian Willison, Warwick Gould, and Warren Chernaik. London: McMillan. 124-150.

Pater, Walter.1986 (1873). The Renaissance: Studies in Art and Poetry. Oxford: World's Classics.

Pollock, Griselda. 1988. Vision and Difference: Femininity, Feminism, 
and Histories of Art. New York: Routledge.

Psomiades, Kathy Alexis. 1997. Beauty's Body: Femininity an Representation in British Aestheticism. Stanford, California: Stanford UP.

Shaffer, Talia, and Kathy Alexis Psomiades, eds. 1999. Women and British Aestheticism. Charlottesville \& London: UP of Virginia.

Woolf, Virginia. 1976. The Letters of Virginia Woolf II. Ed. Nigel Nicolson. London: The Hogarth P.

Woolf, Virginia.1978. The Letters of Virginia Woolf IV. Ed. Nigel Nicolson. London: The Hogarth $\mathrm{P}$.

Woolf, Virginia. 1980a. The Letters of Virginia Woolf VI. Ed. Nigel Nicolson. London: The Hogarth P.

Woolf, Virginia.1980b. The Diary of Virginia Woolf III. Ed. Anne Olivier Bell. Harmondsworth: Penguin.

Woolf, Virginia.1981. The Diary of Virginia Woolf II. Ed. Anne Olivier Bell. Harmondsworth: Penguin.

Woolf, Virginia. 1982. The Diary of Virginia Woolf IV. Ed. Anne Olivier Bell. Harmondsworth: Penguin.

Woolf, Virginia.1984. The Diary of Virginia Woolf V. Ed. Anne Olivier Bell. Harmondsworth: Penguin.

Woolf, Virginia.1985. The Complete Shorter Fiction of Virginia Woolf. Ed. Susan Dick. London: The Hogarth P.

Woolf, Virginia.1987. The Essays of Virginia Woolf II. Ed. Andrew McNeillie. London: The Hogarth P.

Woolf, Virginia. 1992 (1938). Three Guineas. Ed. Morag Shiach. Oxford: OUP.

Woolf, Virginia.1992b. A Woman's Essays: The Selected Essays of Virginia Woolf I. Ed. Rachel Bowlby. Harmondsworth: Penguin.

Woolf, Virginia.1992c. The Crowded Dance of Modern Life: The Selected Essays of Virginia Woolf II. Ed. Rachel Bowlby. Harmondsworth: Penguin.

Woolf, Virginia.1993. Virginia Woolf: Selected Short Stories. Ed. Sandra Kemp. Harmondsworth: Penguin.

Woolf, Virginia. 1994. The Essays of Virginia Woolf IV. Ed. Andrew McNeillie. London: The Hogarth P. 